50 members wrote their considered opinions and recommendations.

The dues schedule was developed after a careful review of the statements made at the hearings and in correspondence and is designed to produce the monies necessary to support the programs and services now in effect as well as new programs and services the membership has indicated, through divisions and other units, it believes necessary. Each level of the dues schedule has been revised upward with a higher percentage upon the upper salary levels. At the other end of the scale, the minimum dues figure reflects the fact that it takes slightly more than $\$ 15$ to maintain a single membership.

The members of the subcommittee recognize that this is a sharp but essential revision of the clues schedule.

In view of rising costs, ALA must continue to subject all of its programs and operations to the closest scrutiny. Fiscal improvements will no doubt be gained by the self-study of units recommended by the Committee on Organization and the Executive Board (Spring 1968 meeting) and the revision of the budgetary process approved by Council at Midwinter in January 1969. Even these measures, how- ever, cannot hold basic costs to the point where creative program development can proceed without such revision of the dues schedule.

The recommended dues schedule was submitted to the Constitution and Bylaws Comimittee with the hope that if Council accept: the changes, the proper amendments implementing the dues increases could be acted on by Council and the Membership without delay. The Subcommittee recommendations must first be approved by Council. If approved, the Committee on Constitution and Bylaws will then present a revision of the Bylaws to implement the Membership Committee's recommendations. The recommended dues revision appears in the Committee on Constitution and Bylaws Report.

The Subcommittee recommended that a provision be made in the Bylaws for continuous review of the ALA dues structure at least every five years, or more frequently when need. ed.

In conclusion, the Committee would like to thank everyone who contributed their time and effort in helping to revise the ALA dues structure.

\title{
NOTES FOR SSS AND ABSS MEMBERS
}

The Subject Specialist Section and its Agriculture and Biological Sciences Subsection are cosponsoring a program meeting on IVednesday, June 25, at 4:00 P.M. during the Atlantic City Annual Conference. The speaker is John Sherrod, Director of the National Agricultural Library, who will give the fourth presentation in a series on science information networks with a paper on "The National Agricultural Library Network: A Progress Report." The series began in 1966 with Foster Mohrhardt's discussion of concepts for a network of biological-agricultural libraries. The next year Dr. Martin Cummings of the National Library of Medicine described the development of the national medical library network, and last year Joe Becker of EDUCOM spoke on the specific planning and initial implementation of the agricultural-biological information network.

Mr. Sherrod's paper, though focused on agricultural libraries, can be expected to reflect his broad experience, first as chief of the Science and Technology Division of the Library of Congress, 1957-63, then as the head of the Information Services and Systems Branch of the Atomic Energy Commission's Division of Technical Information and later as the Division's Assistant Director for Systems Development until appointment in February 1968 to his present post. Among his many special assignments are membership on COSATI, the Federal Library Committee, the National Research Council's Committee on Chemical Information, and the Chemical Abstracts Advisory Board.

The Eunice Rockwell Oberly Memorial Award will also be presented at this meeting for the most notable bibliography published in the field of agriculture or the related sciences in the period 1967-1968. The award was established in 1923 by the friends and colleagues of Miss Oberly, Librarian of the U.S. Bureau of Plant Industry from 1908 until her death in 1921. It is given biennially in odd numbered years. Prior to this year the recipient was chosen by a committee of the Reference Services Division, but in 1968 RSD requested transfer of responsibility to the ABSS because of the subject orientation of the award. Fleming Bennett, Hume Library, University of Florida, is serving as the first ABSS Chairman of the Oberly Memorial Award Committee. Other members of the committee are Margaret Bryant, Wayne Collings, Sam Hitt and Cindy Woodruff.

The list of distinguished winning bibliographies begins in 1925 with Max Meisel's classic three volume Bibliography of American Natural History, 1769-1865 and includes Bibliography of Land Settlement by Louise O. Bercaw 
(1935 award), Bibliography of Eastern Asiatic Botany by Elmer D. Merrill and Egebert Walker (1941 award), Richard Blanchard and Harald Ostvald's Literature of Agricultural Research (1948 award), volume two of the Hunt Botanical Library Catalog covering printed books 1701-1800 compiled by Allan Stevenson (1963 award), Ida Kaplan Langman's A Selected Guide to the Literature on the Flowering Plants of Mexico (1965 award) and, finally, the 1967 award, George Neville Jones' An Annotated Bibliography of Mexican Ferns.

We hope to meet all of our members who are in Atlantic City on June 25 at this joint meeting and count particularly on ABSS members to be on hand to honor the winner of the Oberly Memorial Award. We promise you a stimulating paper, lively discussion and a very brief business session.

Thomas D. Gillies, Chairman, SSS Louise Darling, Chairman, ABSS

\section{NETWORKS FOR KNOWLEDGE GUIDELINES}

ALA's Washington office reports that guidelines for the "Networks for Knowledge," Higher Education Act Title VIII, are in the final stages of preparation by the U.S. Office of Education's Division of College Support. They were drawn up by a task force which included representatives from the fields of teaching, librarianship, and educational broadcasting. However, according to the fiscal year 1970 budget released by President Nixon, implementation of this new program is being "deferred." In other words, no funds were recommended to be appropriated for the coming year. If Congress reinstates the appropriation of $\$ 750,000$ requested in the Johnson budget, Division officials estimate that only "a handful - probably under ten" projects can be funded. Of these, at least one, and possibly two, would involve library networks. Title VIII is not designed to be used exclusively for library networks; whatever money is available must go to support several different types of cooperative efforts.

ACRL Membership

$$
\begin{array}{ll}
\text { April } 30, & 1969 \\
\text { April } 30, & 1968 \\
\text { April } 30, & 1967 \\
\text { April 30, } 1966
\end{array}
$$

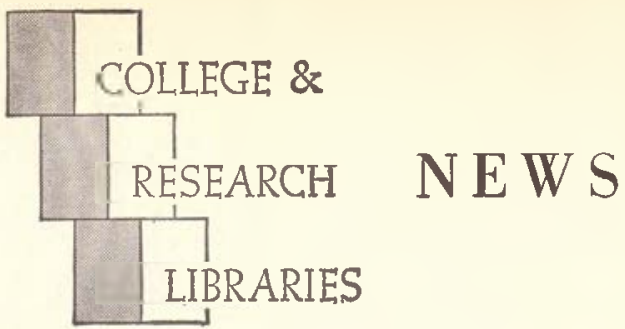

ACRL News Issue of College \& Research Libraries

Editor, David Kaser, Cornell University Libraries, Ithaca, N.Y. 14850.

Managing Editor, Mary Falvey, 50 E. Huron St., Chicago 60611.

News Editor, David Doerrer, Cornell University Libraries, Ithaca, N.Y. 14850.

Editorial Board: JoHn M. DAwson, University of Delaware; Gustave A. Hanfer, University of Florida; Samuel Rothstern, University of British Columbia; JAMES E. SkIPRER, University of California, Berkeley; Norman E. Tanis, Kansas State College of Pittsburg; Maurice F. Tauber, Columbia University; Emleen Thornton, Oberlin College.

ACRL Officers, 1968/69: President, David Kaser; Chairman, College Libraries Section, Evan Ira Farber Junior College Libraries Section, Shirley A. Edsall; Rare Books Section, J. M. Edelstein; Subject Specialists Section. Thomas D. Gillies; Agriculture and Biological Sciences Subsection, Louise Darling; Art Subsection, Herbert G. Scherer; Law and Political Science Subsection, Morris L. Cohen; Slavic and East European Subsection, Dmytro M. Shtohryn; University Libraries Section, G. F. Shepherd.

News from the Field, Personnel profiles and notes, classified advertising, official matter of ACRL, and other material of a timely nature is published in the News issues of College \& Research Libraries.

Inclusion of an article or advertisement in $C R L$ does not constitute official endorsement by ACRL or ALA

Production and Advertising and Circulation office: 50 E. Huron St., Chicago, Ill. 60611. Change of address and orders for subscriptions should be addressed to College \& Research Libraries, for receipt at the above address, at least two months before the publication date of the effective issue.

Subscription to $C R L$ is included in membership dues to $A C R L$ of $\$ 6$ or more; other subscriptions to $C R L$ are $\$ 10$ per year. Neither subscriptions nor memberships include miscellaneous unscheduled supplements, which are available by purchase only. Retroactive subscriptions are not accepted. Single journal copies are available at $\$ 1.50$ each and News issues at $\$ 1.00$ each from ALA Publishing Department.

Indexed in Library Literature. Abstracted in Library Science Abstracts. Book reviews indexed in Book Review Index.

College of Research Libraries is the official journal of the Association of College and Research Libraries, a division of the American Library Association; and is published seventeen times per year-bi-monthly as a technical journal with 11 monthly News issues, combining July-August-at 1201-05 Bluff St., Fulton, Mo. 65251 .

Second-class postage paid at Fulton, Mo. 